\title{
EDITORIAL
}

\section{European Science Editing is in full open access now}

\author{
Ksenija Baždarić \\ ChiefEditor; ese@arphahub.com
}

DOI: $10.3897 /$ ese.2020.e50566

Dear readers,

I am excited to announce that with this volume European Science Editing (ESE) has shifted from the print to a fully digital open access version. The journal underwent several changes last year. First of all, our publisher, the European Association of Science Editors (EASE) was generously offered - and accepted - a new ARPHA submission system (powered by PenSoft). Together with the EASE president Pippa Smart and EASE Council, we decided to transform ESE into a fully open access online journal. After several months of planning and re-thinking our strategy, a small working group (some members of the EASE Council and of ESE's associate editors) prepared a proposal, the main idea of which was to divide the journal in two overlapping publications: European Science Editing and EASE Digest. The former will continue to publish original articles, reviews (formerly "essays"), viewpoints, and correspondence using the fully open access ARPHA submission system (flow publishing) but will drop the other sections, namely News notes, The editor's bookshelf, This site I like, and EASE Forum Digest). These sections, which our readers consider particularly valuable, will now be published in EASE Digest with a few selected articles from ESE. The Digest will be available to EASE members only. As the proposal was accepted by the EASE Council in September 2019, the journal's transformation is already under way. I wish to thank Silvia Maina (This site I like), Fiona Murphy (Book reviews), Elise Langdon-Neuner (EASE-Forum Digest), Anna Maria Rossi (The Editor's bookshelf), and James Hartley and Denys Wheatley (members of the International Advisory Board) for the great work they have done and for their cooperation.

European Science Editing remains the official journal of EASE, and its primary goal and major strength continue to be in informing and training editors, publishers, and other information specialists and in presenting the latest developments in editing and publishing. The main mission of the new editorial board is to continue growing the journal's visibility by publishing more original articles and other items of interest to editors, publishers, and librarians. The journal publishes original contributions related to different aspects of scientific and scholarly editing (for example: research integrity, peer review, scientometrics, open science, predatory publishing, statistics), publishing, writing, translation, and ethics. The aim and vision of the journal is to provide a source of peer-reviewed information on all aspects of scholarly editing and publishing to help editors improve the quality and integrity of publications for which they are responsible. To accomplish this mission, I am honoured and happy to have the following editors working with me on the journal's content: Joan Marsh, Tom Lang, and Hrvoje Jakovac as associate editors; Dado Čakalo as the managing editor; Yateendra Joshi as the copy editor; and Lynne Rowland (the Chief Editor of EASE Digest) as the technical editor.

I am also very happy to announce that ESE has a new editorial board with distinguished members from all over the world: Eva Baranyiová (Czech Republic), Lisa Colledge (UK), Moira Hudson (UK), Olga Kirillova (Russia), Zafer Kocak (Turkey), Rachael Lammey (UK), Vladimir S Lazarev (Belarus), Hervé Maisonneuve (France), Ana Marušić (Croatia), Arjan Polderman (the Netherlands), María del Carmen Ruíz Alcocer (Mexico), Karen Shashok (Spain), Cem Uzun (Turkey), and Quan Hoang Vuong (Vietnam).

Along with other changes, we have a new website (https:// ese.arphahub.com/) under the ARPHA platform. The visual identity of the journal retains the classic EASE format, with blue and white dominating the cover. We hope you will find the new site informative and easy to use. Of course, web pages are not set in stone and our mission is to have a lively site, which we are committed to keeping updated with fresh content and aligned to our readers' needs.

We also have fresh instructions for authors, available at: https://ese.arphahub.com/about\#Instructions-for-authors. All manuscripts to be sent for peer review will be checked for plagiarism with Ithenticate and manually verified. Peer review remains single blind, but reviewers can sign their reports and make them open if they wish. We allow manuscripts that were previously published on preprint servers and encourage data sharing in line with the ICMJE Recommendations. All ESE content will be freely available to all readers, and previously published material will be available on our archive.

I encourage you to comment on our content through our standard channels (correspondence, EASE forum, EASE Twitter, and the Linked-in group) and invite you to share your experiences by contributing to the journal. 